\title{
Analisis Kandungan N-Nitrogen (Amonia, Nitrat, Nitrit) dan Fosfat di Perairan Teluk Pandan Provinsi Lampung
}

\author{
Analysis of N Nitrogen (Ammonia, Nitrate, and Nitric) and Phosphate at Teluk Pandan's \\ Water Territorial, Lampung Province
}

\author{
Reza Iklima $\mathrm{AS}^{1}$, Gusti Diansyah* ${ }^{1)}$, Andi Agussalim ${ }^{1}$, Citra Mulia ${ }^{2}$ \\ ${ }^{1}$ Program Studi Ilmu Kelautan, Fakultas Matematika dan Ilmu Pengetahuan Alam, \\ Universitas Sriwijaya, Indralaya 30662 \\ ${ }^{2}$ Politeknik Negeri Lampung, Jurusan Peternakan, Program Studi Perbenihan Ikan, \\ Kota Bandar Lampung, Lampung 35141 \\ ${ }^{*}$ Penulis untuk korespondensi: diansyah.gusti@gmail.com
}

\begin{abstract}
Teluk Pandan's water territorial was known to aquaculture activity such as prawn, pearl oyster and cage culture by community that lived in the area. It activities could makes water quality to be polluted. This purpose of this research was to known the content of nutrient (Ammonia, Nitrate, Nitric, and Phosphate) and to studied nutrient that related to other's water quality parametric at Teluk Pandan water territorial. Sampling was determinate by 15 station using purposive sampling method. Data analysis was used to studied relation between water quality's parametric using Principal Component Analysis (PCA). Water sampling was taken at surface using water sampler. It was analyze in Oceanography and Instrumentation Laboratory, Department of Marine Science, Universitas Sriwijaya. Result of this research showing that rate of content nutrient at Teluk Pandan's water territory ranging from $0.0007-0.0087 \mathrm{mg} / \mathrm{L} \mathrm{NO} 3-\mathrm{N}$, nitric ranging from 0.0001-0.0062 mg/L NO2-N, and phosphate ranging form 0,0012-0,0091 mg/L PO4-P. Based on result Teluk Pandan's water territory still can be used for water's ecosystem. Result using PCA method showing that correlation between parametric are directly proportional and inversely. Correlation that directly proportional showing by parametric group quadrant I (Temperature, Salinity, Velocity, and Abundance of Phytoplankton), quadrant II (DO, pH and nitrate) and quadrant III (Ammonia, nitric and phosphate). Inversely showing by parametric group quadrant I to parametric group quadrant III.
\end{abstract}

Keywords: n-Nitrogen, Phosphate, PCA, Teluk Pandan

\begin{abstract}
ABSTRAK
Perairan Teluk Pandan telah banyak dimanfaatkan penduduk sekitar untuk berbagai aktivitas perikanan seperti kegiatan budidaya udang, budidaya kerang mutiara dan keramba jaring apung. Banyaknya aktivitas tersebut dapat mempengaruhi kualitas air di perairan. Penelitian ini bertujuan untuk mengetahui kandungan nutrien (amonia, nitrat, nitrit dan fosfat) dan mengkaji keterkaitan antara parameter-parameter kualitas perairan di kawasan Perairan Teluk Pandan. Penentuan titik sampling menggunakan metode purposive sampling sebanyak 15stasiun. Analisis data yang digunakan untuk mengkaji keterkaitan antara parameter-parameter kualitas perairan adalah Principal Component Analysis (PCA). Sampel air diambil di permukaan perairan menggunakan water sampler. Analisis sampel dilakukan di Laboratorium Oseanografi dan Instrumentasi Program Studi Ilmu Kelautan
\end{abstract}


Universitas Sriwijaya. Hasil penelitian menunjukkan bahwa kandungan rata-rata nutrien di perairan Teluk Pandan berkisar antara 0,0111 - 0,0791 mg/L NH3-N untuk amonia, nitrat berkisar antara $0,0007-0,0087 \mathrm{mg} / \mathrm{L}$ NO3-N, nitrit berkisar antara 0,0001 - 0,0062 $\mathrm{mg} / \mathrm{L}$ NO2-N, serta fosfat berkisar antara 0,0012 - 0,0091 mg/L PO4-P. Secara umum kualitas perairan Teluk Pandan masih tergolong baik untuk kehidupan biotaperairan. Hasil analisis menggunakan metode PCA menunjukkan adanya korelasi yang berbanding lurus dan berbanding terbalik antar kelompok parameter. Korelasi yang berbanding lurus ditunjukkan oleh kelompok parameter kuadran I(suhu, salinitas, kecepatan arus dan kelimpahan fitoplankton), kuadran II (DO, pH dan nitrat) dan kuadran III (amonia, nitrit dan fosfat). Korelasi yang berbanding terbalik ditunjukkan oleh kelompok parameter pada kuadran I terhadap kelompok parameter pada kuadran III.

Kata kunci: n-Nitrogen, Fosfat, PCA, Teluk Pandan

\section{PENDAHULUAN}

Perairan Teluk Pandan merupakan perairan yang berada di Kabupaten Pesawaran Provinsi Lampung. Pada perairan ini terdapat aktivitas perikanan seperti budidaya udang, budidaya kerang mutiara dan keramba jaring apung. Pada daerah tersebut juga terdapat sungai yang bermuara ke perairan Teluk Pandan. Sungai tersebut dapat membawa limbah dari daratan seperti limbah dari budidaya udang, pertanian dan pemukiman penduduk. Selain itu di pesisir perairan Teluk Pandan juga terdapat habitat mangrove yang diasumsikan juga dapat memberikan kontribusi terhadap kandungan nutrien pada perairan tersebut. Konsentrasi nutrien di dalam air adalah salah satu faktor yang mempunyai peranan penting terhadap kesuburan perairan. Secara alamiah konsentrasi nutrien bervariasi untuk masing-masing bentuk senyawanya, namun dalam kondisi tertentu dapat terjadi keadaan di luar batas yang dinyatakan aman untuk kategori perairan tertentu. Kondisi yang dimaksud misalnya terjadinya pembuangan limbah yang melewati ambang batas baku mutu yang telah ditetapkan pada daerah tersebut. Akibatnya akan terjadi penurunan kualitas perairan yang berdampak negatif terhadap biota yang hidup di perairan tersebut (Santoso, 2006).

Nutrien yang paling dibutuhkan oleh organisme adalah unsur nitrogen danfosfor (Risamasu dan Prayitno, 2011). Kedua unsur ini memiliki peran penting bagi pertumbuhan fitoplankton yang biasa digunakan sebagai indikator kualitas air dan tingkat kesuburan suatu perairan. Nitrogen di perairan berupa nitrogen organik dan anorganik. Nitrogen anorganik berupa amonia, ammonium, nitrat, nitrit dan molekul nitrogen sedangkan nitrogen organik berupa protein, asam amino dan urea. Fosfor di perairan tidak ditemukan dalam bentuk bebas sebagai elemen tetapi dalam bentuk anorganik yang terlarut berupa orthofosfat dan polifosfat serta organik berupa partikulat. Orthofosfat adalah bentuk fosfat yang dapat dimanfaatkan secara langsung oleh organisme akuatik (Effendi, 2000). Tujuan penelitian ini adalah untuk mengetahui analisis kualitas air di Teluk Pandan, Provinsi Lampung serta untuk mengetahui kandungan nutrien (amonia, nitrat, nitritdan fosfat) dan mengkaji keterkaitan antara parameter-parameter kualitas perairandi kawasan Perairan Teluk Pandan.

\section{BAHAN DAN METODE}

Penelitian ini dilaksanakan pada bulan April 2016 di Perairan Teluk Pandan Provinsi Lampung. Pengambilan sampel air dan fitoplankton dilaksanakan pada Tanggal 6 April 2016 sedangkan analisis sampel air dan fitoplankton dilaksanakan pada Tanggal 11-23 April 2016. Analisis kandungan amonia, nitrat, nitrit dan fosfat dilakukan di Laboratorium Oseanografi dan Istrumentasi Program StudiIlmu Kelautan Fakultas Matematika dan Ilmu Pengetahuan Alam. 
Stasiun pengambilan sampel pengambilan sampel yakni berdasarkan ditentukan dengan metode Purposive keterwakilan lokasi sehingga ditetapkan Sampling yaitu teknik penentuan sampel sebanyak 15 stasiun di sekitar perairan dengan pertimbangan tertentu (Sugiyono, Teluk Pandan (Gambar 1).

2012). Pertimbangan penentuan stasiun

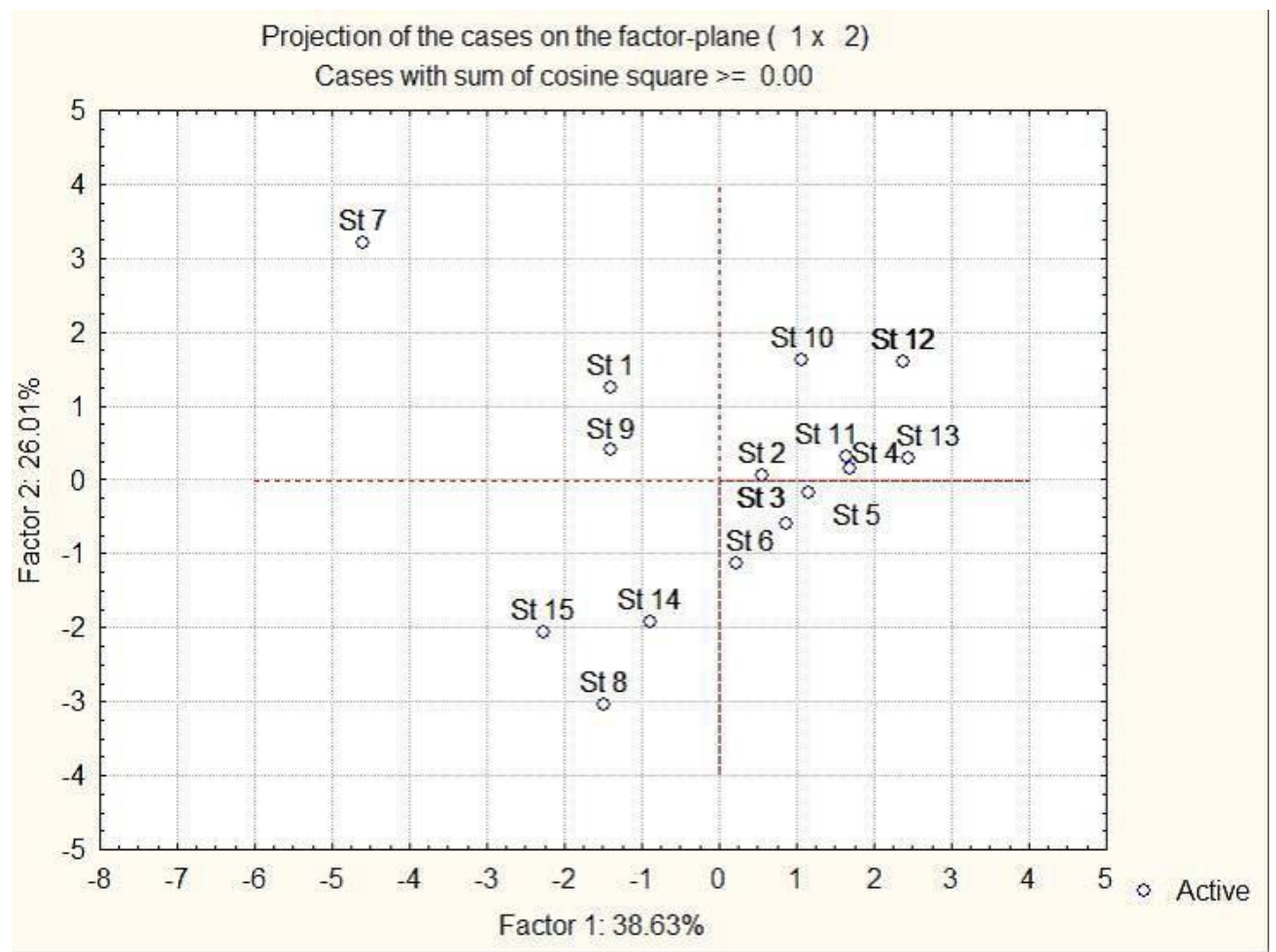

Gambar 1. Sebaran stasiun di Teluk Pandan menggunakan metode PCA

\section{Analisis dan Pengukuran Sampel Air di Laboratorium}

Analisis sampel air mengacu pada APHA (2005) yang dilakukan dengan menggunakan spektrofotometer UV mini1240. Analisis sampel amonia dilakukan metode phenate dan diukur pada panjang gelombang $640 \mathrm{~nm}$. Analisis sampel nitrat dilakukan dengan metode Brucine dan diukur pada panjang gelombang $410 \mathrm{~nm}$. Analisis sampel nitrit dilakukan dengan metode Sulfanilamide dan diukurpada panjang gelombang $543 \mathrm{~nm}$. Analisis sampel fosfat dilakukan dengan metode Asam Ascorbic dan diukur pada panjang gelombang $880 \mathrm{~nm}$. Konsentrasi nutrien pada air sampel dihitung dengan persamaan Lambert-Beer:

\section{$\mathbf{A}=\boldsymbol{E} \times \mathbf{b} \times \mathbf{C}$}

Dimana :
$\mathrm{A}=$ Nilai absorbansi

$\mathcal{E}=$ Nilai a dari persamaan regresi

$\mathrm{b}=$ Tebal kuvet $(=1)$

$\mathrm{C}=$ Konsentrasi nutrien pada air sampel

\section{Analisis Kelimpahan Fitoplankton}

Perhitungan kelimpahan

fitoplankton dilakukan dengan Sedwick

Rafter Counter Cell (SRCC) setelah dilakukan pencacahan dengan menggunakan alat bantu mikroskop cahaya. Kelimpahan fitoplankton dihitung dalam sel/liter menggunakan persamaan Djumanto et al. (2009).

\section{Analisis Data \\ Parameter Perairan}

Data hasil analisis amonia, nitrat, nitrit dan fosfat dan parameter lingkungan meliputi DO, pH, salinitas, suhu serta arah dan kecepatan arus yang diukur diolah menggunakan Microsoft Excel yang 
kemudian akan diplotkan ke dalam petalokasi pengambilan sampel dengan menggunakan perangkat lunak Surfer 9 (Gambar 2). Hasil dari interpolasi kemudian disajikan dalam bentuk kontur secara horizontal. Penyajian pola sebaran horizontal secara visualisasi dilakukan untuk memberikan keterangan yang lebih informatif sesuai dengan data hasil pengukuran dan kemudian dianalisis secara deskriptif dan dibandingkan dengan baku mutu perairan menurut Kepmen LH No 51 Tahun 2004.

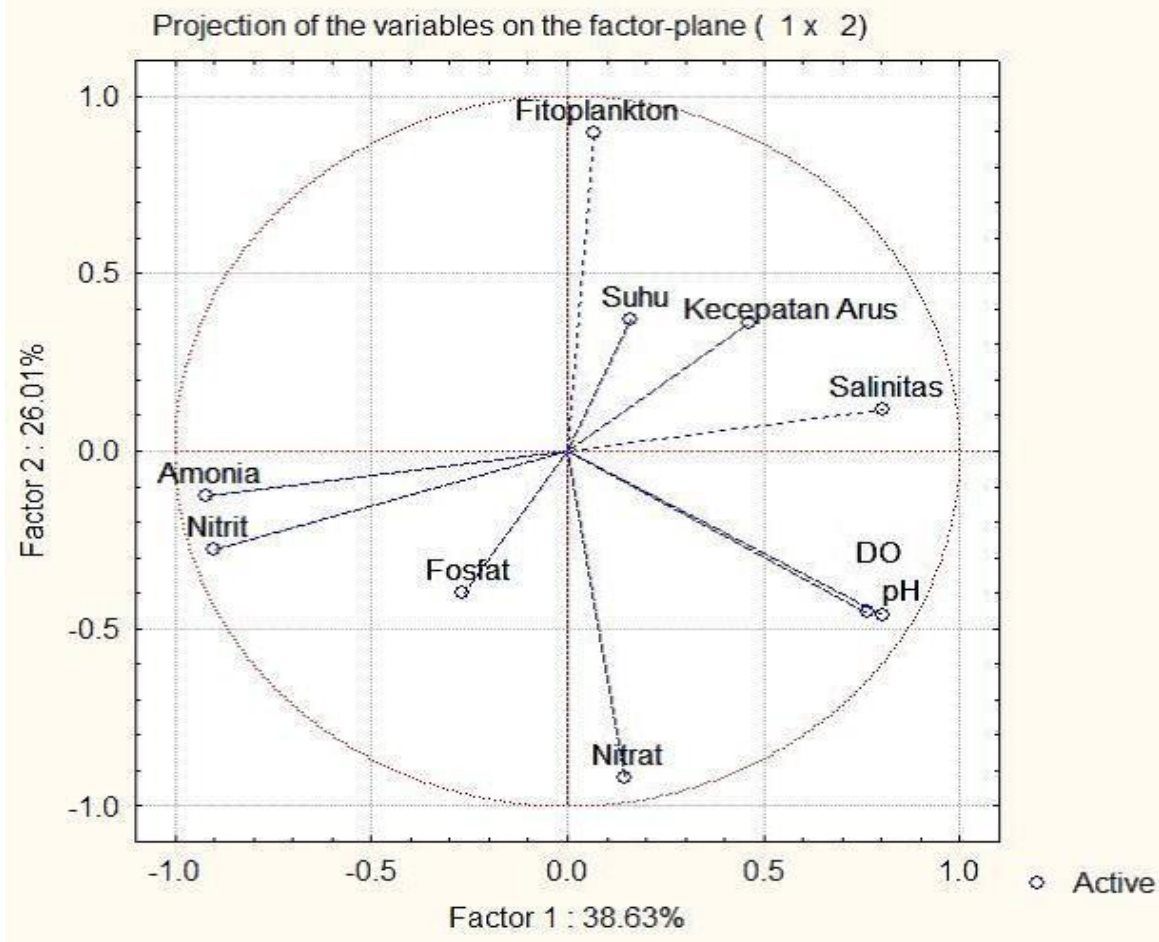

Gambar 2. Parameter Lingkungan secara keseluruhan dan kemelimpahan fitoplankton pada 15 stasiun di Teluk Pandan menggunakan metode PCA

\section{Analisis Komponen Utama}

Analisis keterkaitan antar parameter perairan dilakukan dengan menggunakan metode analisis komponen utama. analisis komponen utama atau Principal Component Analysis (PCA) merupakan metode statistik deskriptif yang bertujuan untuk menyajikan informasi maksimum suatu matriks data ke dalam bentuk grafik. Untuk mendeterminasi sebaran karakteristik fisika-kimia antar stasiun pengamatan, digunakan pendekatan analisis statistik multivariabel yang didasarkan pada analisis komponen utama dengan menggunakan perangkat lunak Statistica 8.0 (Bengen, 2000).

Hasil PCA tidak direalisasikan dari nilai-nilai parameter inisial, tapi darimatriks sintetik yang diperoleh dari kombinasi linier nilai parameter. Korelasilinier antar dua parameter yang dihitung dari indeks sintetiknya adalah peragam dari kedua parameter tersebut. Diantara semua indeks sintetik yang mungkin, didalam PCA dicari terlebih dahulu indeks yang menunjukkan ragam stasiun maksimumnya. Indeks ini disebut komponen indeks utama pertama yang merupakan sumbu utama (F1) dan memberikan informasi terbesar dari ragam totalstasiun. Selanjutnya dicari komponen utama kedua (F2) yang memiliki korelasi nihil dengan komponen utama dan memberikan informasi terbesar kedua sebagai pelengkap komponen utama pertama. 


\section{HASIL DAN PEMBAHASAN}

\section{Parameter Nutrien}

Amonia(NH3-N)

Hasil pengukuran amonia di perairan Teluk Pandan berkisar antara 0,0111-0,0791 mg/L NH3-N dengan ratarata $0,0442 \mathrm{mg} / \mathrm{L} \mathrm{NH} 3-\mathrm{N}$.

\section{Nitrat (NO3-N)}

Hasil pengukuran nitrat di perairan Teluk Pandan berkisar antara 0,0007$0,0087 \mathrm{mg} / \mathrm{L}$ NO3-N dengan rata-rata 0,0049 mg/L NO3-N.

\section{Nitrit (NO2-N)}

Berdasarkan hasil pengukuran nitrit di perairan Teluk Pandan berkisar antara 0,0001-0,0062 mg/L NO2-N dengan ratarata $0,0032 \mathrm{mg} / \mathrm{L} \mathrm{NO} 2-\mathrm{N}$.

\section{Fosfat (PO4-P)}

Hasil penelitian yang dilakukan di perairan Teluk Pandan kandungan fosfatdi lokasi penelitian berkisar antara 0,0012 0,0091 mg/L PO4-P dengan rata-rata0,0033 $\mathrm{mg} / \mathrm{L}$ PO4-P. Kadar fosfat tertinggi terdapat di stasiun 8 sedangkan kadar fosfat terendah terdapat pada stasiun 7 (Gambar 3).

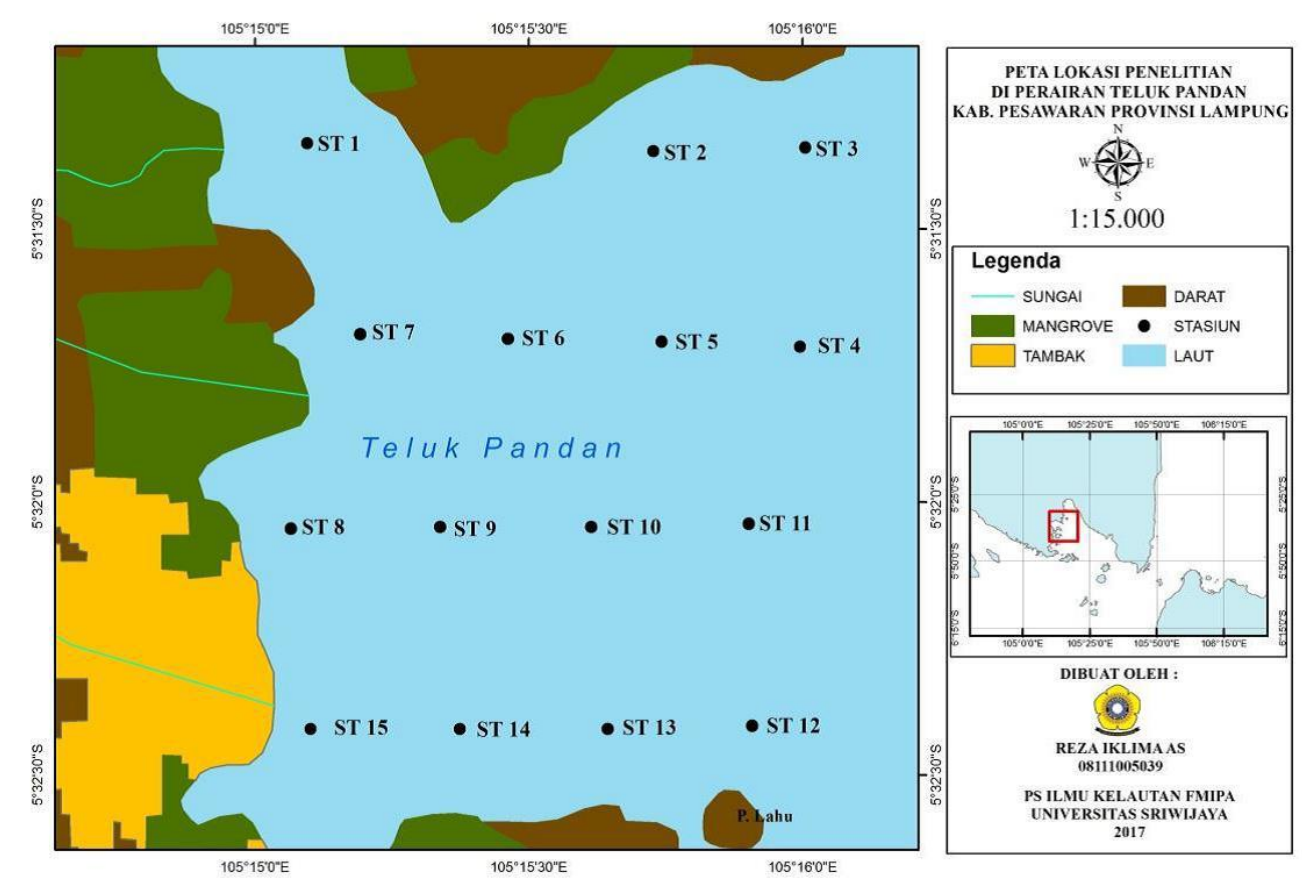

Gambar 3. Lokasi Penelitian mengambil tempat di Teluk Pandan, Provinsi Lampung. Penelitian dilakukan menggunakan 15 stasiun

\section{Parameter Nutrien}

\section{Amonia(NH3-N)}

Berdasarkan KepMENLH NO. 51

Tahun 2004 kandungan amonia di perairan Teluk Pandan masih dalam batas baku mutu air laut untuk biota laut yakni sebesar 0,3 $\mathrm{mg} / \mathrm{L}$.

Berdasarkan pola sebaran amonia dapat dilihat konsentrasi amonia pada teluk bagian luar lebih rendah dibandingkan teluk bagian dalam. Hal ini di duga disebabkan oleh konsentrasi $\mathrm{pH}$ yang semakin tinggi ke arah teluk bagian luar (Gambar 3). Menurut
Effendi (2000) amonia di peraiaran dapat menghilang melalui proses volatilisasi karena tekana parsial amonia dalam lautan meningkat dengan semakin meningkatnya $\mathrm{pH}$.

Stasiun 7 merupakan stasiun dengan nilai konsentrasi paling tinggi pada lokasi penelitian dan stasiun 12 merupakan stasiun dengan nilai konsentrasi amonia yang paling rendah. Stasiun 1 dan 15 juga mempunyai kadar amonia yang cukup tinggi di bandingkan stasiun-stasiun lainnya. Tingginya konsentrasi amonia pada 
stasiun ini jika dilihat dari faktor lingkungan, lokasi stasiun 7 ini merupakan lokasi yang dekat dengan kegiatan budidaya keramba jaring apung (KJA) yang menyebabkan banyaknya bahan organik di sekitar titik pengambilan sampel (Gambar 4).

\section{Nitrat (NO3-N)}

Berdasarkan Kep MENLH NO. 51 Tahun 2004 kandungan nitrat di perairan Teluk Pandan masih berada dalam baku mutu air laut untuk biota laut yakni sebesar $0,008 \mathrm{mg} / \mathrm{L}$.

Pola sebaran nitrat dapat dilihat bahwa konsentrasi nitrat tertinggi terdapat pada stasiun 8 dan terendah pada stasiun 7 . Tingginya konsentrasi nitrat pada stasiun 8 ini jika dilihat berdasarkan faktor dari daratan dimana daerah tersebut merupakan daerah tambak dan dekat dengan kegiatan budidaya keramba jaring apung (KJA) yang dapat mempengaruhi konsentrasi nitrat di daerah tersebut. Rendahnya kadar nitrat pada stasiun 7 diduga ada hubungannya dengan kelimpahan fitoplankton yang tinggi pada stasiun pengambilan sampel. Menurut Fitriyah (2011) dalam Muchtar (2012) rendahnya kadar nitrat dilapisan permukaan disebabkan oleh fitoplankton yang telah memanfaatkan zat hara nitrat untuk pertumbuhan dan perkembangan (Gambar 5).

\section{Nitrit (NO2-N)}

Menurut Sawyer dan McCarty (1978) dalam Effendi (2000) kadar nitrit di perairan jarang $>1 \mathrm{mg} / \mathrm{L}$. Kadar nitrit yang lebih dari $0,05 \mathrm{mg} / \mathrm{L}$ dapat bersifat toksik bagiorganisme. Pola sebaran nitrit di perairan.

Secara umum dari pola sebaran nitrit dapat dilihat pada daerah stasiun 7 merupakan stasiun dengan konsentrasi nitrit paling tinggi pada lokasi penelitian dan stasiun 13 merupakan stasiun dengan nilai konsentrasi nitrit yang paling rendah. Stasiun 15 juga mempunyai konsentrasi nitrit yang cukup tinggi dibandingkan stasiun-stasiun lainnya. Tingginya konsentrasi nitrit pada stasiun ini jika dilihat dari faktor lingkungan diduga disebabkan oleh rendahnya konsentrasi oksigen terlarut pada stasiun pengambilan sampel. Hutagalung dan Rozak (1997) mengatakan bahwa konsentrasi senyawa nitrit akan semakin meningkat dengan semakin rendahnya oksigen terlarut (Gambar 6).

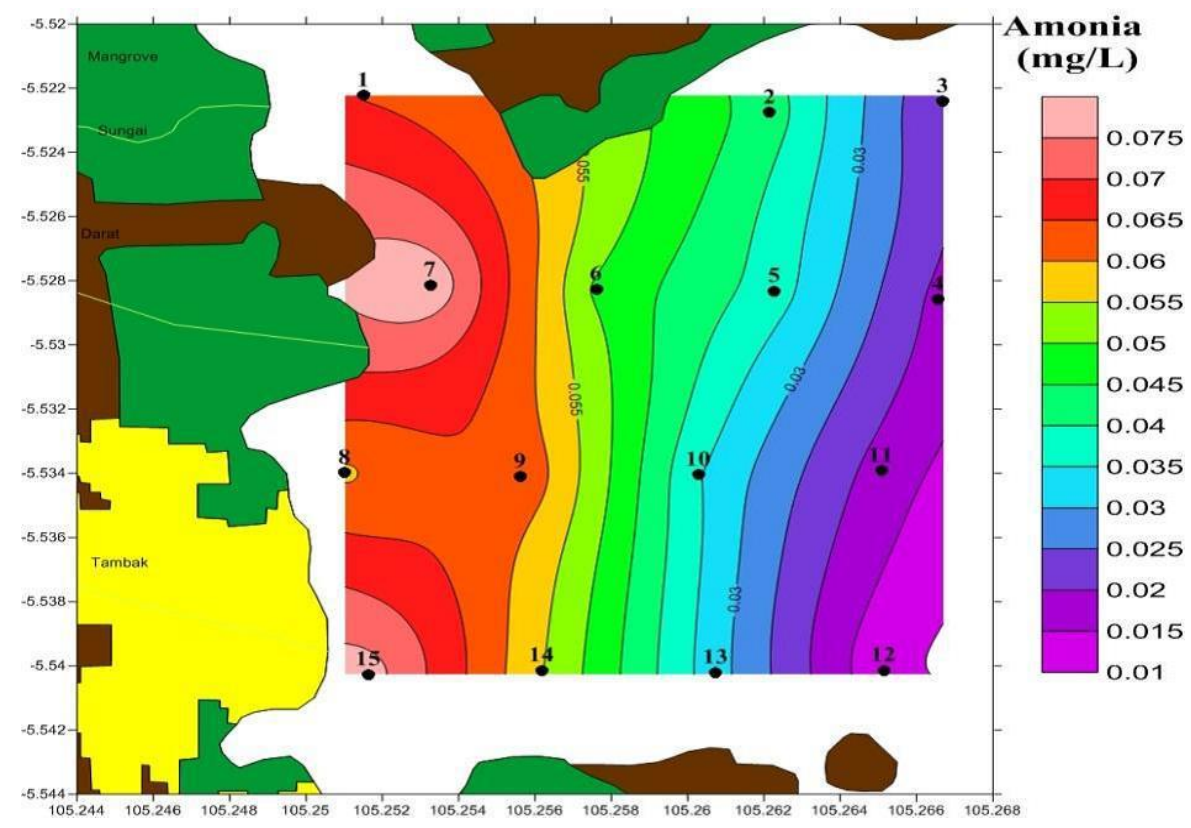

Gambar 4. Pola Sebaran Amonia pada 15 stasiun di Teluk Pandan menggunakan PCA 


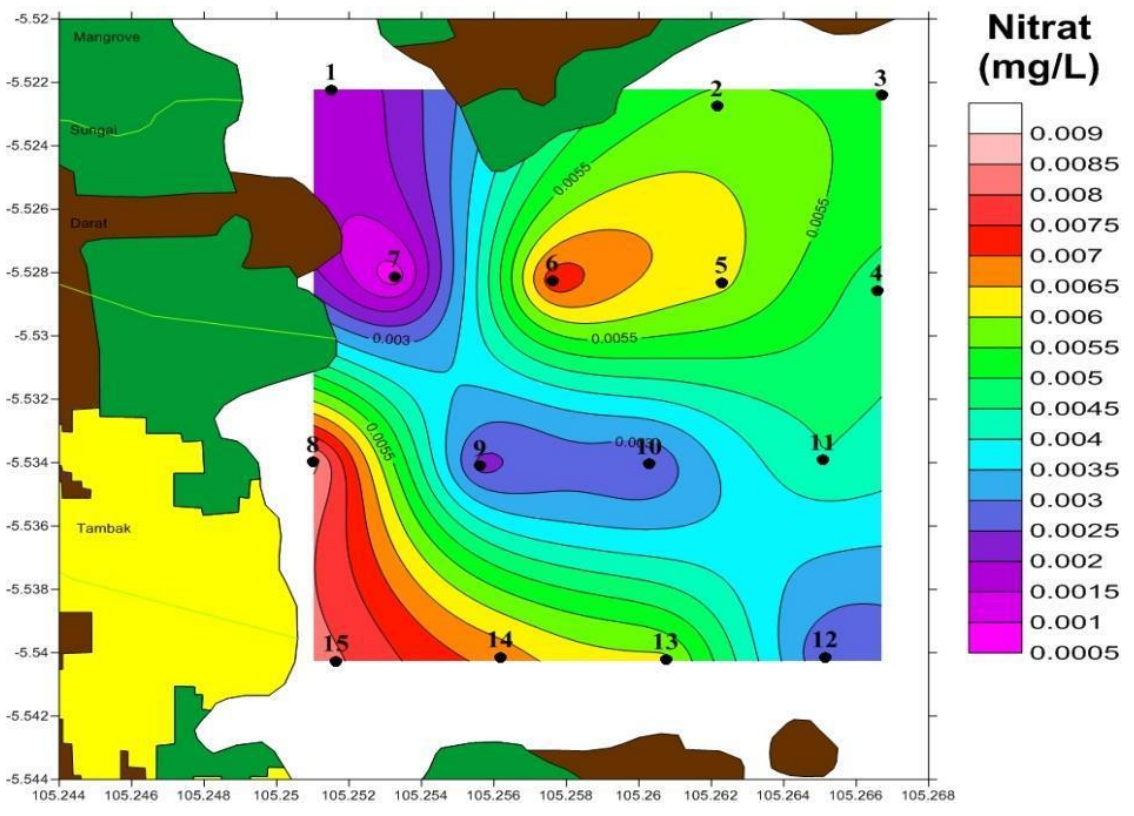

Gambar 5. Pola sebaran nitrat pada 15 stasiun di Teluk Pandan menggunakan metode PCA

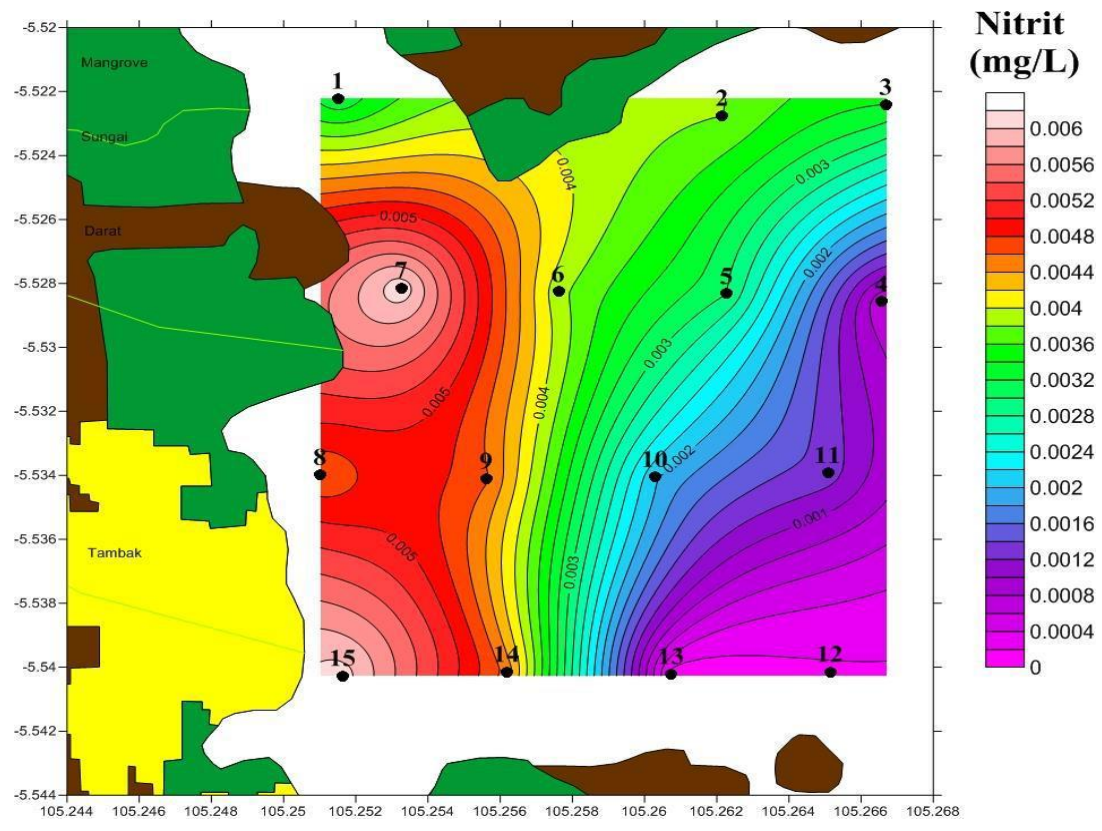

Gambar 6. Pola sebaran nitrit pada 15 stasiun di Teluk Pandan menggunakan metode PCA

\section{Fosfat (PO4-P)}

Berdasarkan KepMENLH NO. 51 Tahun2004 untuk biota maka kandungan fosfat dalam perairan Teluk Pandan masih berada di bawah baku mutu perairan yang ditetapkan yaitu sebesar $0,015 \mathrm{mg} / \mathrm{L}$.

Berdasarkan pola sebaran fosat dapat dilihat konsentrasi fosfat pada teluk bagian luar lebih rendah dibandingkan teluk bagian dalam. Hal ini di duga disebabkan oleh semakin tingginya salinitas ke arah teluk bagian luar (Gambar 5).Hal ini sesuai dengan Effendi (2000) yang mengatakan semakin tinggi salinitas umumnya kadar orthofosfat di perairan semakin rendah (Gambar 7).

\section{Kelimpahan Fitoplankton}

Hasil pengamatan yang telah dilakukan terhadap kelimpahan fitoplankton 
diperairan Teluk Pandan didapatkan hasil yang bervariasi dari setiap stasiun pengamatan. Kelimpahan fitoplankton yang teramati berkisar antara 95.709-590.545 Ind/Liter dengan rata-rata 383.379 Ind/Liter. Kelimpahan fitoplankton tertinggi di perairan Teluk Pandan terdapat pada stasiun 7 sedangkan kelimpahan terendah terdapat 15 . Tingginya kelimpahan fitoplankton pada stasiun 7 diduga disebabakan karena letak titikstasiun pengambilan sampel berada pada daerah budidaya Keramba Jaring Apung (KJA) yang diasumsikan bahwa daerah tersebut terdapat banyak nutrien untuk pertumbuhan fitoplankton.

Hasil analisis data kelimpahan fitoplankton di perairan Teluk Pandan mengindikasikan bahwa perairan tersebut tergolong subur. Merujuk pada kriteria menurut Lander (1978) dalam Suryanto dan Umi (2009) yang menyatakan apabila kelimpahan lebih dari 15000 Ind/Liter dinyatakan perairan tersebut tergolong subur.

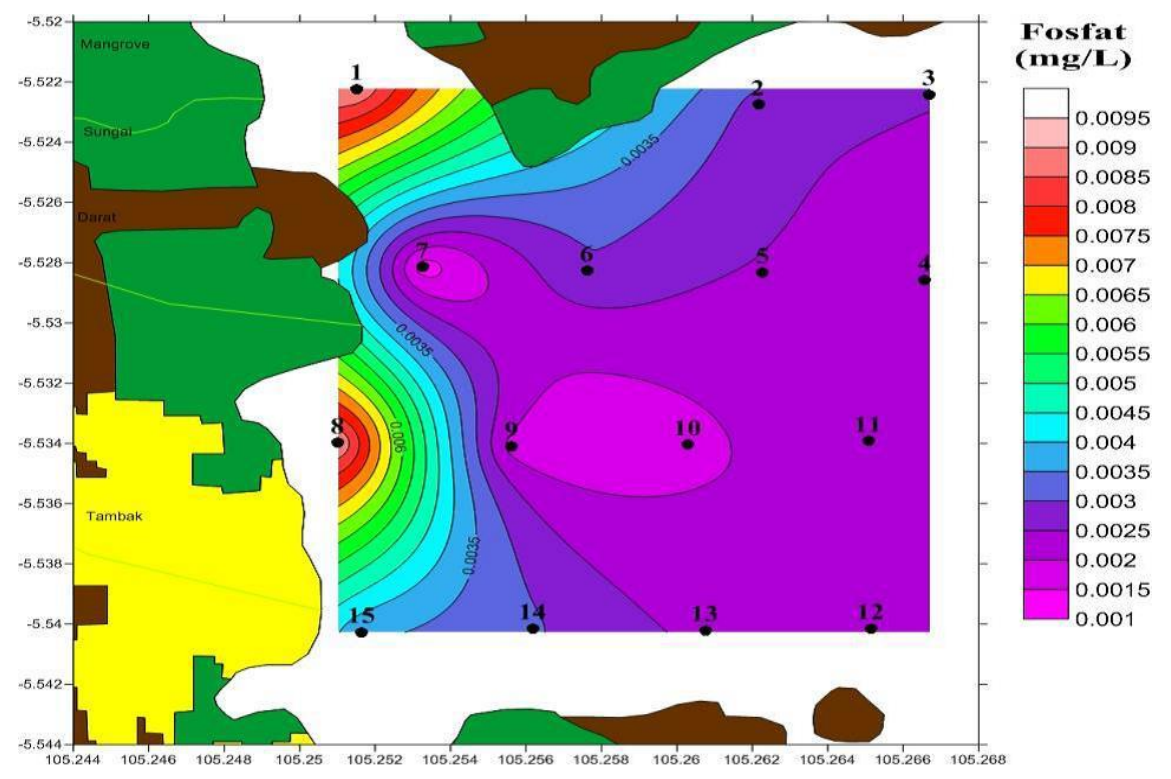

Gambar 7. Pola Sebaran Fosfat pada 15 stasiun di Teluk Pandan menggunakan metode PCA

\section{Analisis Komponen Utama}

Faktor-faktor yang berpengaruh serta karakteristik parameter fisikia, kimia dan biologi dapat diketahui dengan menggunakan pendekatan analisis komponen utama atau Principal Component Analysis (PCA). Adapun parameter yang diperhitungkan yaitu amonia, nitrat, nitrit, fosfat dan kelimpahan fitoplankton selain itu juga ditambahkan parameter lingkungan antara lain $\mathrm{pH}$, suhu, salinitas, DO dan kecepatan arus.

Hasil analisis memperlihatkan bahwa informasi penting terhadap sumbuterpusat pada empat sumbu utama (F1, F2, F3 dan F4) dengan kontribusi masing masing sumbu sebesar $38,62 \%$,
26,01, 13,51 dan $8,16 \%$ dari ragam total sebesar 86,31\%. Pembahasan ini menunjukkan hasil analisis komponen utama pada sumbu F1 dan F2 sebagai sumbu dengan kontribusi paling besar dari sumbulainnya yaitu sebesar $64,63 \%$. Sumbu F1 positif menunjukkan parameter nitrat, DO dan $\mathrm{pH}$. Sumbu F2 positif menunjukkan parameter fitoplankton, suhu, kecepatan arus dan salinitas sedangkan sumbu F2 negatif menujukkan parameteramonia, nitrit dan fosfat.

Keberadaan parameter pada posisi sumbu F1 positif dan F1 negatif maupunF2 positif dan F2 negatif memiliki pengertian bahwa hubungan karakter parameter yang 
bersifat keterbalikan. Sebagai contoh pada sumbu F2 kadar fosfat di perairanakan rendah saat salinitas dan kelimpahan fitoplankton di perairan tersebut tinggi.

Berdasarkan grafik terlihat korelasi yang bebanding lurus dan berbanding terbalik antar parameter. Korelasi yang berbanding lurus terjadi pada kelompok parameter yang berada pada satu kuadran seperti pada kuadran I (fitoplankton, suhu, kecepatan arus dan salinitas ), kuadran II (nitrat, DO dan pH),dan kuadran III (amonia, nitrit dan fosfat). Korelasi yang berbanding terbalik antara kelompok parameter yaitu kelompok parameter pada kuadran I terhadap kelompok parameter pada kuadran III.

Berdasarkan grafik tersebut dapat dilihat pengelompokan stasiun yang terdiri dari empat kelompok. Kelompok ke-I terdiridari stasiun 2, 4, 10, 11, 12 dan 13 yang dicirikan oleh parameter kelimpahan fitoplankton, suhu, kecepatan arus dan salinitas. Kelompok ke-II terdiri daristasiun 3, 5 dan 6 yang dicirikan oleh nitrat, DO dan $\mathrm{pH}$. Kelompok ke-III terdiri dari stasiun 8,14 dan 15 yang dicirikan oleh parameter amonia, nitrit dan fosfat, sedangkan kelompok ke-IV terdiri dari stasiun 1, 7 dan 9. Pengelompokan stasiun ini didasarkan pada karakter kelompok parameter yang umumnya bernilai tinggi pada stasiunstasiun tersebut.

\section{KESIMPULAN}

Kandungan ammonia di perairan Teluk Pandan berkisar antara 0,01110,0791 mg/L NH3-N, nitrat berkisar antara $0,0007-0,0087 \quad \mathrm{mg} / \mathrm{L} \quad \mathrm{NO} 3-\mathrm{N}$,nitrit berkisar antara 0,0001-0,0062 mg/L NO2$\mathrm{N}$ dan fosfat berkisar antara 0,0012 0,0091 mg/L PO4-P. Secara umum kualitas perairan Teluk Pandan masih tergolong baik untuk kehidupan biota perairan.

Adanya korelasi yang berbanding lurus dan berbanding terbalik antar kelompok parameter. Korelasi yang berbanding lurus terjadi pada kelompok parameter yang berada pada satu kuadran seperti pada kuadran I (suhu, salinitas, kecepatan arus dan kelimpahan fitoplankton), kuadran $\mathrm{II}(\mathrm{DO}, \mathrm{pH}$ dan nitrat) dan kuadaran III (amonia, nitrit dan fosfat). Korelasi yang berbanding terbalik antara kelompok parameter yaitu kelompok parameter pada kuadran I terhadap kelompok parameter pada kuadran III.

Saran yang dapat diberikan pada penelitian selanjutnya ialah sebaiknya dilakukan pengambilan sampel pada saat pasang dan surut sehingga dapat diketahui perbedaan konsentrasi amonia, nitrat, nitrit dan fosfat pada saat pasang dan surut.

\section{UCAPAN TERIMA KASIH}

Penulis mengucapkan terimakasih yang sebesar-besarnya kepada para reviewer atas bantuannya untuk mereview jurnal kami:

1. Agus Arifin Sentosa, S. Pi, M, Si (alumnus UGM, Peneliti di KKP)

2. Arfiani Rizki Paramata, S. Pi, M, Si (alumnus UGM, Dosen Universitas Negeri Gorontalo)

3. Cahyani Pratisti, S. Pi, M. M (alumnus UGM, Dosen Universitas Darmajaya)

\section{DAFTAR PUSTAKA}

APHA (American Public Health Association). 2005. 'Inorganic Non Metallic Constituents in Standard Methods for the Examination of Water and Wastewater', A.D. Eaton, L.S. Clesceri, E.W. Rice, A.E. Greenberg (Eds.) 21st ed.,: American Public.

Bengen DG. 2000. 'Teknik Pengambilan Contoh dan Analisis Data Biofisik Sumberdaya Pesisir'. Bogor: Pusat Kajian Sumberdaya Pesisir dan Lautan. IPB. $86 \mathrm{hlm}$.

Djumanto, Tumpak S, Hanny P, Reinhard L. 2009. 'Pola sebaran horizontal dan kerapatan plankton di perairan Bawean'. Jurnal Perikanan. 11(1): 115-122. 
Effendi H. 2003. 'Telaah Kualitas Air Bagi Pengeloaan Sumber Daya Lingkungan Perairan'. Yogyakarta: Kanisius. $258 \mathrm{hlm}$.

Effendi H. 2000. 'Telaah Kualitas Air Bagi Pengeloaan Sumber Daya Lingkungan Perairan'. Bogor: Institut Pertanian Bogor. $259 \mathrm{hlm}$.

Hutagalung HP, Rozak A. 1997. 'Metode Analisis Air Laut, Sedimen dan Biota'. Jakarta : Pusat Penelitian dan Pengembangan Oseanologi-LIPI. $175 \mathrm{hlm}$.

Keputusan Menteri Lingkungan Hidup No. 51 Tahun 2004. Tentang Baku MutuAir Laut.

Muchtar M. 2012. 'Distribusi Zat Hara Fosfat, Nitrat dan Silikat di perairan Kepulauan Natuna'. Jurnal Ilmu dan Teknologi Kelautan Tropis. 4(2): 304-317.
Risamasu FJL, Prayitno. 2011. 'Kajian Zat Hara Fosfat, Nitrit, Nitrat dan Silikat di Perairan Kepulauan Matasari Kalimantan Selatan'. Jurnal Perikanan Kalautan. 16(3):135-142.

Santoso AD. 2006. 'Kualitas Nutrien Perairan Teluk Hurun Lampung. 'Jurnal Teknologi Lingkungan. 7(2): 140-144.

Sugiyono. 2012. Metode Penelitian Kuantitatif Kualitatif dan R \& D. Bandung : Alfabeta. $380 \mathrm{hlm}$.

Suryanto AM, Umi H. 2009. 'Pendugaan Status Trofik dengan Pendekatan Kelimpahan Fitoplankton dan Zooplankton di Waduk Sengguruh, Karangkates, Lahor, Wlingi Raya dan Wonorejo Jawa Timur'. Jurnal Ilmiah Perikanan dan Kelautan. 1(1):7. 